\title{
PHYSICAL, MECHANICAL AND THERMAL PROPERTIES OF WOOD/ ZEOLITE/PLASTIC HYBRID COMPOSITES
}

\author{
Alperen Kaymakci, ${ }^{1, \mathrm{~s}}$,Turker Gulec ${ }^{2}$, Seyyed Khalil Hosseinihashemi ${ }^{3}$, Nadir Ayrilmis ${ }^{4}$
}

\begin{abstract}
Effect of zeolite content on the physical, mechanical and thermal properties of wood plastic composites was investigated in this study. To meet this objective, pine wood flour $(0,10,20,30,40$, $50 \mathrm{wt} \%)$ with compatibilizing agent, zeolite $(0,10,20,30,40,50 \mathrm{wt} \%)$, and polypropylene were compounded in a twin screw co-rotating extruder. The mass ratio of the wood flour to polypropylene was $50 / 50(\mathrm{w} / \mathrm{w})$ in all compounds. Test specimens were produced using injection molding machine from the pellets. Physical and mechanical, and thermal (Thermogravimetry Analysis/Differential Scanning Calorimetry) properties of the wood plastic composites were determined. The water absorption and thickness swelling properties of wood plastic composites improved with increasing zeolite content. The flexural and tensile properties of the wood plastic composites decreased with increasing zeolite content. All the wood plastic composites provided the values of flexural strength $(58,4-72,9 \mathrm{MPa})$ and flexural modulus (2718-5024 MPa) that were well over the requirement by the standard specified in ASTM D 6662. The mass loss rates values of wood plastic composites increased with increasing zeolite contents. The Differential Scanning Calorimetry analysis showed that the melt crystallization enthalpies and degree of crystallization of wood plastic composites decreased with increasing zeolite content. The decrease in the $\mathrm{T}_{\mathrm{c}}$ and $\mathrm{X}_{\mathrm{c}}$ indicated that zeolite was the poor nucleating agent for the wood plastic composites.
\end{abstract}

Keywords: Pinus sylvestris, swelling, thermoplastic composites, technological properties, thermal stability.

\section{INTRODUCTION}

New kinds of biobased materials produce from renewable resources, such as lignocellulosic material are becoming more attractive. The principal reason for this can be related to global environmental problems and the need for a green development in society (Naik et al. 2007). Green development can only be probable when production uses renewable materials or materials recycled from wastes. As a consequence of the increasing demand for eco-friendly materials and the high cost of synthetic fibres, new biobased materials containing natural fibres were developed (Kidalova et al. 2012, Yorur 2016, Mengeloglu and Karakus 2008, Kordkheili et al. 2013, Safdari et al. 2011).

Wood plastic composites (WPC) define as composite materials containing lignocellulosic (in various forms) and thermoplastic materials are a relatively new family of composite materials. In such

\footnotetext{
${ }^{1}$ Kastamonu University, Forestry Faculty, Department of Wood Mechanics and Technology, Kastamonu, Turkey.

${ }^{2}$ Artvin Coruh University, Forestry Faculty, Department of Wood Product Chemistry and Technology, Artvin, Turkey.

${ }^{3}$ Deparment of Wood Science and Paper Technology, Karaj Branch, Islamic Azad University, Karaj, Iran.

${ }^{4}$ Deparment of Wood Mechanics and Technology, Forest Faculty, Istanbul University, Turkey.

•Corresponding author: akaymakci@kastamonu.edu.tr

Received: 14.10.2016 Accepted: 30.03.2017
} 
composites, a natural fiber/filler (such as kenaf fiber, wood flour (WF), hemp, sisal, etc.) is mixed with a thermoplastic (e.g., polyethylene, polypropylene, PVC, etc.) to produce a WPC (Najafi et al. 2005, Ayrilmis et al. 2013, Yemele et al. 2010, Ayrilmis and Kaymakci 2013, Bledzki and Gassan 1999, Demir et al. 2006, Valles-Rosales et al. 2016b). Generally, WPC formulation consists of over $50 \%$ WF, thus its characteristics play a critical role in determining the WPC processing parameters as well as final product properties. To produce WPCs, wood residuals, e.g. sawdust, wood shavings or WF, are mixed with a thermoplastic polymer and melt processed (or thermoformed) into its final shape, either as a continuous profile forming through extrusion or as a three dimensional form through injection molding. During recent decades, WPCs have rapidly increased their market share as a building material (Carus and Gahle 2008). Despite the recent economic downturn, which has leveled off this growth, a continued global market advance is predicted (Anonymus 2011, Bledzki et al. 1998). This success may partly be attributed to the fact that WPCs are a competitive alternative to tropical hardwoods and that they are considered to require less maintenance than conventional wood products. Using WPCs, it is also possible to manufacture more complex shapes than with solid wood products, with a raw material yield close to $100 \%$. A growing demand for WPCs has led to continuous efforts to find new resources as alternative to wood. With the increasing population of the world, the sustainable utilization of forest resources has been adversely influenced.

Zeolites are hydrated crystalline aluminosilicates with microporous nanostructures and pore sizes ranging from about 3-15 $\AA$. The structure of zeolites consists of 3-dimensional frameworks made up by $\mathrm{SiO}_{4}$ and $\mathrm{AlO}_{4}$ tetrahedra. They possess permanent negative charges in their structural framework, which has the capability of adsorbing or rejecting molecules, thus they are widely used in catalysis, separation, adsorption and ion-exchange (Wang et al. 2015). Zeolites can be used to reinforce composites or as agents to improve their mechanical properties and crystallinity behavior of polymer (Chang et al. 2013). The addition of zeolites to natural-flour-filled thermoplastic polymer composites is an effective method of reducing their odor and VOC emissions without any degradation of their mechanical and thermal properties (Ki and Kim 2008).

There is a lot of studies on the effects of filler such as WF, wheat straw, nanoclays and carbon nanotube on the physical, mechanical and thermal performance of WPCs. (Khonsari et al. 2015, Samariha et al. 2015, Aydemir et al. 2016, Valles-Rosales et al. 2016a, Nafchi et al. 2015). But, currently there is little information available concerning on effect of zeolites mining on mechanical, physical, and thermal properties of WPCs. For this reason, this study was to examine effect of zeolite as well as compatibilizer agent (MAPP) used in experimental polypropylene (PP) and pine wood flour (WF) composites on their physical, mechanical and thermal properties. The major weakness is a poor compatibility between wood and plastic. The effect of the zeolite powder on the interfacial bonding between wood flour and polymer matrix was also investigated in this study.

\section{EXPERIMENTAL}

\section{Materials}

Pine WF (Pinus sylvestris L.) with mesh size of 60 was provided by Wood Plastic Decking Factory, Tekirdağ, Turkey. Polypropylene (PP) with a density of $0,9 \mathrm{~g} / \mathrm{cm}^{3}$ was purchased from Borealis Incorp in Austria. It has a melt point $170{ }^{\circ} \mathrm{C}$ and a melt flow index of $2,5 \mathrm{~g} / 10 \mathrm{~min}$ at $230{ }^{\circ} \mathrm{C}$. Zeolite was obtained from Rota Mining Co. İstanbul, Turkey. The compatibilizing agent, maleic anhydride grafted polypropylene (MAPP) (Optim-425) was supplied by Pluss Polymers Pvt. Ltd. Gurgaon, India. It has a density $0,91 \mathrm{~g} / \mathrm{cm}^{3}$ and a melt flow index about $120 \mathrm{~g} / 10 \mathrm{~min}$ at $190{ }^{\circ} \mathrm{C}$.

\section{WPC preparation}

Before manufacturing processes, the WF was dried in a vacuum oven at $103 \pm 2{ }^{\circ} \mathrm{C}$ for 24 -h to a moisture content of $0-1 \%$ based on the oven-dry weight of wood. The dried WF was stored in a plastic bag. Then the PP, WF, zeolite, and MAPP were weighed and bagged according to formulations given in Table 1. 
Table 1. Compositions of the injection molded WPC formulations.

\begin{tabular}{|c|c|c|c|c|}
\hline \multirow[b]{2}{*}{ Composite type } & \multicolumn{4}{|c|}{ Composite compositon } \\
\hline & $\begin{array}{l}\text { Wood flour } \\
\quad(\text { wt } \%)\end{array}$ & $\begin{array}{c}\text { Zeolite } \\
(\%)\end{array}$ & $\begin{array}{l}\text { Polypropylene } \\
\text { (wt \%) }\end{array}$ & $\begin{array}{l}\text { Coupling agent } \\
\text { (MAPP) } \\
(\text { wt } \%)\end{array}$ \\
\hline A & 50 & - & 50 & $\frac{(w / \%)}{3}$ \\
\hline $\mathrm{B}$ & 40 & 10 & 50 & 3 \\
\hline $\mathrm{C}$ & 30 & 20 & 50 & 3 \\
\hline $\mathrm{D}$ & 20 & 30 & 50 & 3 \\
\hline $\mathrm{E}$ & 10 & 40 & 50 & 3 \\
\hline $\mathrm{F}$ & - & 50 & 50 & 3 \\
\hline
\end{tabular}

The PP, WF, zeolite and MAPP granulates were processed in a $30 \mathrm{~mm}$ co-rotating twin-screw extruder with a length-to-diameter (L/D) ratio of 30:1. The barrel temperature of the extruder was controlled at $175-190{ }^{\circ} \mathrm{C}$. The extruded strand passed through a water bath and was subsequently pelletized. The pellets were dried again at $103 \pm 2{ }^{\circ} \mathrm{C}$ for $2 \mathrm{~h}$ before the injection molding. From the compounds which had been granulated, specimens were injection molded by injection molding machine (TSPX 60, China) at molding temperature of $180^{\circ} \mathrm{C}$. The injection pressure was 3-5 MPa. The test specimens were conditioned at $23{ }^{\circ} \mathrm{C}$ and a relative humidity of $50 \%$ in a climate room until they reached constant weight. This was important because all the specimens should reach equilibrium moisture content prior to testing.

\section{Methods}

\section{Physical Tests}

Test samples measuring $2 \mathrm{~mm}$ x $50 \mathrm{~mm}$ x $50 \mathrm{~mm}$ were used for the thickness swelling (TS) and water absorption (WA) determination according to ISO 62 procedures. The conditioned specimens were entirely immersed for 1-day, 7-days, and 14-days in a container of water at $23 \pm 2{ }^{\circ} \mathrm{C}$. At the end of each immersion time, the samples were taken out from the water and all surface was removed with a clean dry cloth. The specimens were weighed to the nearest $0,01 \mathrm{~g}$ and measured to the nearest 0,001 $\mathrm{mm}$ immediately. Twelve replicate samples were tested for each wood plastic composite formulation.

\section{Mechanical tests}

The flexural and tensile tests were measured according to the ISO 178 and ISO 527, respectively, using a Lloyd universal testing machine (Model LS 100, England), The tests were performed at crosshead speeds of $5 \mathrm{~mm} / \mathrm{min}$. Twelve replicate specimen were tested for both flexural and tensile strength measurements.

\section{Thermogravimetry Analysis (TGA) and Differential Scanning Calorimetry (DSC)}

The injected pellets were grinded with a Willey mill prior to analysis. Thermo-gravimetric analysis of the samples was done by using the Perkin Elmer STA 6000 thermal analyzer. For the TGA test, the specimens having a weight between $17-20 \mathrm{mg}$ were heated from 50 to $600{ }^{\circ} \mathrm{C}$ at a heating rate of 20 ${ }^{\circ} \mathrm{C} / \mathrm{min}$. Additionally, melting and crystallization behavior of the WPNs were studied in a heat-flux type differential scanning calorimeter (DSC, Pelkin Elmer DSC 4000) according to ASTM D3418. The test samples weighing about 9-10 mg in an aluminum crucible were heated up to $250{ }^{\circ} \mathrm{C}$ with the heating rate of $10^{\circ} \mathrm{C} / \mathrm{min}$ and kept at this temperature for $2 \mathrm{~min}$ to remove thermal history. Then the samples were cooled down to $0{ }^{\circ} \mathrm{C}$ with the cooling rate of $10{ }^{\circ} \mathrm{C} / \mathrm{min}$ by an electrical cooling device. All heating-cooling runs in melting and crystallization studies were carried out under nitrogen $\left(\mathrm{N}_{2}\right)$ atmosphere at a flow rate of $30 \mathrm{ml} / \mathrm{min}$ to prevent oxidation of the samples. 


\section{Statistical analysis}

An analysis of variance, ANOVA, was conducted $(p<0,05)$ to evaluate the effect of the zeolite content on the physical, mechanical and thermal properties of the wood polymer composites. Significant differences among the average values of the wood polymer nanocomposites types were determined using Duncan's multiple range tests.

\section{RESULT AND DISCUSSION}

\section{Dimensional Stability}

The results of air-dry density, TS and WA performed on the WPC samples are presented in Table 2. The air-dry density of the composites ranged from 1,03 to $1,17 \mathrm{~g} / \mathrm{cm}^{3}$. As compared to the wood flour, the TS and WA of the WPCs significantly improved with increasing amount of the zeolite. The integration of WF into the plastic matrix resulted in high TS and WA values due to the hydrophilic nature of WF, as estimated. The specimen types presenting significant differences with further groups according to Duncan's multiple-range tests are shown by superscript letters in Table 2 . The lowest TS value was obtained to be $0,06 \%$ for the specimens containing $50 \mathrm{wt} \%$ zeolite and MAPP after $24 \mathrm{~h}$ (1 day) of submersion in water, whereas the highest TS value was obtained to be $0,98 \%$ for the samples containing $50 \% \mathrm{WF}$ and MAPP after 14 day of submersion in water.

Table 2. Physical properties of the WPCs filled with wood flour and zeolite.

\begin{tabular}{|c|c|c|c|c|c|c|c|}
\hline \multirow{2}{*}{ WPC Type $^{1}$} & \multicolumn{7}{|c|}{ Water Resistance } \\
\cline { 2 - 8 } & \multirow{2}{*}{ Density $\left(\mathrm{g} / \mathrm{cm}^{3}\right)$} & \multicolumn{3}{|c|}{ Water Absorption (\%) } & \multicolumn{3}{c|}{ Thickness Swelling (\%) } \\
\cline { 3 - 8 } & $1,03 \mathrm{a}$ & $0,21 \mathrm{a}$ & $0,48 \mathrm{a}$ & $0,59 \mathrm{a}$ & $0,48 \mathrm{a}$ & $0,66 \mathrm{a}$ & $0,98 \mathrm{a}$ \\
\multirow{2}{*}{$\mathbf{A}$} & $(0,004)$ & $(0,10)$ & $(0,06)$ & $(0,12)$ & $(0,05)$ & $(0,12)$ & $(0,04)$ \\
\hline \multirow{2}{*}{$\mathbf{B}$} & $1,07 \mathrm{~b}$ & $0,16 \mathrm{~b}$ & $0,43 \mathrm{~b}$ & $0,55 \mathrm{a}$ & $0,43 \mathrm{a}$ & $0,60 \mathrm{ab}$ & $0,91 \mathrm{~b}$ \\
& $(0,005)$ & $(0,04)$ & $(0,06)$ & $(0,08)$ & $(0,13)$ & $(0,38)$ & $(0,05)$ \\
\hline \multirow{2}{*}{$\mathbf{C}$} & $1,09 \mathrm{c}$ & $0,12 \mathrm{bc}$ & $0,33 \mathrm{c}$ & $0,41 \mathrm{~b}$ & $0,34 \mathrm{~b}$ & $0,47 \mathrm{bc}$ & $0,85 \mathrm{c}$ \\
& $(0,004)$ & $(0,07)$ & $(0,02)$ & $(0,04)$ & $(0,06)$ & $(0,04)$ & $(0,04)$ \\
\hline \multirow{2}{*}{$\mathbf{D}$} & $1,10 \mathrm{~d}$ & $0,10 \mathrm{bc}$ & $0,26 \mathrm{~d}$ & $0,37 \mathrm{~b}$ & $0,29 \mathrm{bc}$ & $0,39 \mathrm{~cd}$ & $0,75 \mathrm{~d}$ \\
& $(0,01)$ & $(0,03)$ & $(0,07)$ & $(0,05)$ & $(0,07)$ & $(0,12)$ & $(0,04)$ \\
\hline \multirow{2}{*}{ E } & $1,17 \mathrm{e}$ & $0,08 \mathrm{c}$ & $0,19 \mathrm{e}$ & $0,26 \mathrm{c}$ & $0,26 \mathrm{c}$ & $0,32 \mathrm{~cd}$ & $0,64 \mathrm{e}$ \\
& $(0,006)$ & $(0,02)$ & $(0,04)$ & $(0,07)$ & $(0,05)$ & $(0,03)$ & $(0,08)$ \\
\hline \multirow{2}{*}{ F } & $1,15 \mathrm{f}$ & $0,03 \mathrm{~d}$ & $0,06 \mathrm{f}$ & $0,12 \mathrm{~d}$ & $0,06 \mathrm{~d}$ & $0,22 \mathrm{~d}$ & $0,46 \mathrm{f}$ \\
& $(0,013)$ & $(0,02)$ & $(0,02)$ & $(0,02)$ & $(0,03)$ & $(0,02)$ & $(0,06)$ \\
\hline
\end{tabular}

${ }^{1}$ See Table 1 for WPC formulation.

The value in parenthesis is the standard deviation, Groups with same letters in column indicate that there is no statistical difference $(\mathrm{p}<0,05)$.

The TS percent for the 24-hour water-immersed specimen varied from $0,48 \%$ to $0,06 \%$ for the WPC specimens. These values increased after 14 days of immersion, varying from $0,98 \%$ to $0,46 \%$ for the WPC samples. Similar to TS properties, the lowest WA value was obtained to be $0,03 \%$ for the samples including $50 \mathrm{wt} \%$ zeolite and MAPP after $24 \mathrm{~h}$ (1 day) of submersion in water, whereas the highest WA value was obtained to be $0,59 \%$ for the samples containing $50 \% \mathrm{WF}$ and MAPP after 14 day of submersion in water. The WA percent for the 24-hour water-immersed samples varied from $0,21 \%$ to $0,03 \%$ for the WPC specimens. These values increased after 14 days of immersion, changing from $0,59 \%$ to $0,12 \%$ for the WPC samples. 
Due to the hydrophilic nature of the wood, the moisture absorption is high, which leads to weak interfacial adhesion between the WF and polypropylene, which makes debonding. For improving interfacial bonding between the WF and polymer matrix, the MAPP which was one of the efficient compatibilizer agents in WPC industry was used in the production of the composites (Demir et al. 2006). Anhydride part of the MAPP forms ester bonds with wood's hydroxyl groups and the long hydrophobic polymer incorporates into the polymer network. MAPP is therefore a functional modifier. Consequently, the wood fibers and the polymer matrix become bonded together, resulting in enhanced mechanical properties and reduced moisture absorption (Väisänen 2016).

The TS and WA decreased with increasing zeolite content in the polypropylene composites - a trend that is expected for 1 day and 7 and 14 days water immersion tests. With the increase in the zeolite content, there are less water residence spaces, thus less water is absorbed. However, the samples containing a high content of WF have more hydroxyl groups reacted with water molecules, which results higher TS and WA. The lowest TS and WA value were found in the specimens containing 0 $\mathrm{wt} \%$ zeolite after 1-day submersion in water, whereas the highest TS and WA values were obtained for the samples containing $50 \mathrm{wt} \% \mathrm{WF}$ after 14-days of submersion in water. The samples produced with lower content of the zeolite had lower TS and WA values.

\section{Mechanical Properties}

The significant differences $(\mathrm{p}<0,05)$ were found in the values of the flexural strength and modulus of elasticity (MOE). The significant differences between the composite groups are displayed in Table 3 .

Table 3. Mechanical properties of the WPCs filled with wood flour and zeolite.

\begin{tabular}{|c|c|c|c|c|}
\hline \multirow{2}{*}{$\begin{array}{c}\text { WPC } \\
\text { type }^{1}\end{array}$} & \multicolumn{4}{|c|}{ Mechanical properties } \\
\cline { 2 - 5 } & Flexural strength & $\begin{array}{c}\text { Modulus of elasticity } \\
\text { in bending }\end{array}$ & Tensile strength & $\begin{array}{c}\text { Modulus of } \\
\text { elasticity in tensile }\end{array}$ \\
\cline { 2 - 5 } & $(\mathrm{MPa})$ & $(\mathrm{MPa})$ & $(\mathrm{MPa})$ & $(\mathrm{MPa})$ \\
\hline $\mathbf{A}$ & $70,8(2,79) \mathrm{a}^{2}$ & $3200(743) \mathrm{ad}$ & $41,5(0,77) \mathrm{a}$ & $1336(206) \mathrm{a}$ \\
\hline $\mathbf{B}$ & $72,9(3,38) \mathrm{a}$ & $5024(478) \mathrm{b}$ & $42,1(0,54) \mathrm{a}$ & $1411(121) \mathrm{a}$ \\
\hline $\mathbf{C}$ & $64,9(2,82) \mathrm{b}$ & $4372(1005) \mathrm{c}$ & $34,8(0,49) \mathrm{b}$ & $1173(117) \mathrm{b}$ \\
\hline $\mathbf{D}$ & $62,2(2,87) \mathrm{bc}$ & $4061(254) \mathrm{c}$ & $32,0(0,57) \mathrm{c}$ & $1121(163) \mathrm{bc}$ \\
\hline $\mathbf{E}$ & $59,5(0,90) \mathrm{cd}$ & $3602(457) \mathrm{cd}$ & $31,47(1,18) \mathrm{cd}$ & $1061(55) \mathrm{bc}$ \\
\hline F & $58,4(1,94) \mathrm{d}$ & $2718(310) \mathrm{a}$ & $30,94(0,98) \mathrm{d}$ & $1008(118) \mathrm{c}$ \\
\hline
\end{tabular}

The value in parenthesis is the standard deviation, Groups with same letters in column indicate that there is no statistical difference $(\mathrm{p}<0,05)$.

The flexural strength and MOE values of the WPC specimens decreased with increasing zeolite content from 10 to $50 \%$ in the composite. For example, the average flexural strength and modulus of elasticity values of the WPCs containing $50 \mathrm{wt} \% \mathrm{WF}$ (Group A) were found to be 70,8 and 3200 $\mathrm{MPa}$ as compared to the WPCs containing $50 \mathrm{wt} \%$ zeolite (Group F), which were about 58,4 and $2718 \mathrm{MPa}$, respectively. However, for polyolefin-based plastic lumber decking boards, ASTM D 6662 standard requires the minimum flexural strength of $6,9 \mathrm{MPa}$ and flexural modulus of $340 \mathrm{MPa}$. All the composites produced in this study provided flexural strength values $(58,4-72,9 \mathrm{MPa})$ and flexural modulus (2718-5024 MPa) that are well over the requirement by the standard. In a former report, the modulus of elasticity values were obtained to be $5336 \mathrm{MPa}$ for WPCs produced from $47 \% \mathrm{PP}$ and $50 \%$ hardwood WF respectively (Ayrilmis and Kaymakci 2013).

Wood is a lignocellulosic material made up of three major constituents (42-44\% cellulose, $27-28 \%$ hemicelluloses, and $24-28 \%$ lignin). The major percentage of wood is cellulose. The aligned fibril structure of the cellulose, along with strong hydrogen bonds, has a high stiffness; thus, the addition of WF can increase the stiffness of thermoplastic composites (Walker 2006, Uysal and Yorur 2013). As shown in Table 3, the flexural strength and modulus of elasticity values of the composites containing WF were significantly higher than those in the composites containing zeolite. This could be explained by the improved interfacial adhesion between polypropylene and the WF due to the compatibilizing 
agent (MAPP). According to Bledzki and Gassan (1999) an increase in the wood plastic composite strength could be related with higher cellulose and lignin contents. This provide better dispersion and adhesion to the polymer matrix. The lower flexural strength and modulus of elasticity values of the composites containing high zeolite contents were also attributed to the lower fibrous zones in the zeolites. The observed decrease in flexural strength and modulus of elasticity indicated that the zeolites could not act as a reinforcing agent inside the WPC matrix. These findings propose that the desirable content of zeolites was $10 \%$ of the production of WPCs (Group B). Similar results were reported by Wang et al. (2015). They stated that extreme zeolite content could form agglomerates inside the WPC matrix and act as micro crack initiator, thus playing an adverse role in the mechanical performance.

The findings of the tensile properties of the samples with WF and zeolite are given in Table 3 . Adding zeolite to the polypropylene significantly decreased the tensile properties of the WPC samples. The tensile strength and tensile modulus values of the WPC specimens decreased with increasing zeolite content from 10 to $50 \mathrm{wt} \%$ in the WPC. For example, the average tensile strength and tensile modulus values of the WPCs containing $50 \mathrm{wt} \% \mathrm{WF}$ (Group A) were 41,5 MPa and $1336 \mathrm{MPa}$ as compared to composites containing 50\% zeolite (Group F), which were about $30,94 \mathrm{MPa}$ and 1008 $\mathrm{MPa}$, respectively. The decrease in the tensile properties was mainly attributed to the weak interfacial adhesion between the WF, zeolite and the polypropylene matrix, as reported in previous paper Wang et al. (2015). In all the WPC groups, the WPCs with the zeolite had lower tensile strength and tensile modulus (except composite group B). Ashori and Nourbakhsh (2009) reported that the strength of the wood plastic composites was mainly influenced by the interfacial adhesion between wood and polymer matrix. Better interfacial adhesion between particles and matrix results into more restriction to deformation capacity of the matrix in the elastic zone and increased strength and modulus (Ashori and Nourbakhsh 2009).

\section{TGA and DSC analysis}

TGA test curves of WPCs filled with WF and zeolite samples are shown in Figures 1 and 2 (Table 4). From the figures, it was observed that zeolite could change the thermal stability of the WPCs. As can be clearly seen from Figures 1 and 2, the thermal degradation of all WPCs was comprised of two stages. All the WPC groups were moderately stable up to the temperature above $200{ }^{\circ} \mathrm{C}$, which was higher than the process temperatures for the twin-screw extruder and injection molding (Figure 1). The first peaks were observed around $230{ }^{\circ} \mathrm{C}$ for WPCs filled with the WF and zeolite while the second peaks were around $420^{\circ} \mathrm{C}$ for wood plastic composites. As shown in Figure 1, the highest weight loss was found in the specimens containing $50 \mathrm{wt} \% \mathrm{WF}$ while the lowest weight loss was found in the specimens containing $50 \mathrm{wt} \%$ zeolite.

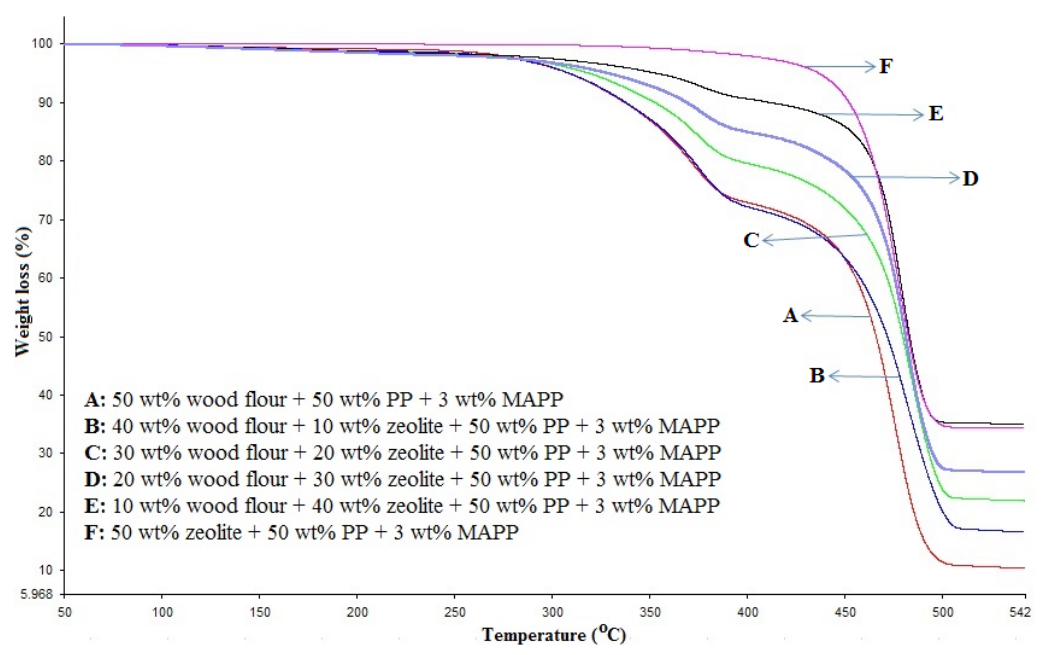

Figure 1. TGA results of wood plastic composites. 


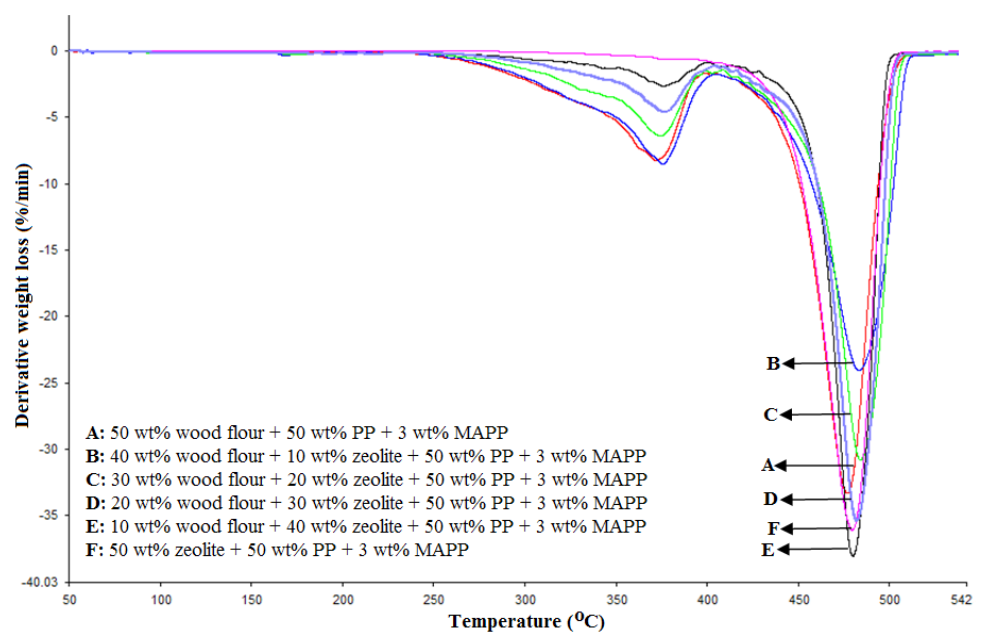

Figure 2. Derivative weight loses result of wood plastic composites.

Table 4. The results of Thermogravimetric analysis (TGA).

\begin{tabular}{|c|c|c|c|c|c|c|c|}
\hline \multirow[b]{2}{*}{ WPC code ${ }^{1}$} & \multicolumn{3}{|c|}{ 1st region } & \multicolumn{3}{|c|}{ 2nd region } & \multirow{2}{*}{$\begin{array}{c}\text { Residue } \\
\text { at } \\
520^{\circ} \mathrm{C} \\
(\%)\end{array}$} \\
\hline & Range $\left({ }^{\circ} \mathrm{C}\right)$ & $\begin{array}{l}\text { Peak } \\
\left({ }^{\circ} \mathrm{C}\right)\end{array}$ & Weight loss (\%) & Range $\left({ }^{\circ} \mathrm{C}\right)$ & $\begin{array}{l}\text { Peak } \\
\left({ }^{\circ} \mathrm{C}\right)\end{array}$ & $\begin{array}{c}\text { Weight } \\
\text { loss }(\%)\end{array}$ & \\
\hline A & $238,15-395,10$ & 318,48 & 36,669 & $405,31-511,22$ & 452,86 & 33,483 & 10,736 \\
\hline B & $233,00-402,93$ & 319,29 & 41,854 & $408,46-515,09$ & 458,46 & 32,900 & 16,976 \\
\hline $\mathrm{C}$ & $233,34-400,02$ & 321,06 & 30,582 & $409,33-512,56$ & 462,35 & 41,028 & 22,214 \\
\hline $\mathrm{D}$ & $241,91-401,10$ & 330,26 & 19,866 & $410,86-510,19$ & 462,20 & 43,438 & 26,914 \\
\hline $\mathrm{E}$ & $240,51-398,19$ & 328,23 & 11,530 & $404,11-504,30$ & 461,38 & 56,726 & 35,179 \\
\hline $\mathrm{F}$ & - & - & - & $385,49-505,91$ & 452,57 & 82,222 & 34,442 \\
\hline
\end{tabular}

${ }^{1}$ See Table 1 for WPC formulation.

The crystallization peak temperature $\left(\mathrm{T}_{c}\right)$ of the WPCs with the WF was higher than that of those with zeolite, indicating that the WF which was a conductive filler could act as nucleating agents (Table $5)$.

Table 5. The results of differential scanning calorimetry (DSC) analysis.

\begin{tabular}{|c|c|c|c|c|c|c|c|}
\hline $\begin{array}{l}\text { WPC } \\
\text { code }^{1}\end{array}$ & $\mathbf{T}_{\mathrm{m} \cdot \mathrm{I}}{ }^{\mathrm{b}}\left({ }^{\circ} \mathrm{C}\right)$ & $\mathrm{T}_{\text {c. } 0}{ }^{\mathrm{c}}\left({ }^{0} \mathrm{C}\right)$ & $T_{\text {c. } p}{ }^{d}\left({ }^{0} \mathrm{C}\right)$ & $\begin{array}{l}\Delta \mathbf{H}_{\mathrm{c}}{ }^{{ }^{2}} \\
(\mathrm{~J} / \mathbf{g})\end{array}$ & $\mathbf{T}_{\mathrm{m} \text {. II }}{ }^{\mathrm{f}}$ & $\begin{array}{c}\Delta \mathbf{H}_{\mathrm{II}}{ }^{\mathrm{g}} \\
(\mathbf{J} / \mathbf{g})\end{array}$ & $X c^{h}(\%)$ \\
\hline A & 165,2 & 131,0 & 127,5 & 48,9 & 166,2 & 33,2 & 31,8 \\
\hline B & 165,8 & 130,0 & 126,3 & 55,6 & 165,6 & 42,7 & 40,8 \\
\hline C & 165,2 & 129,3 & 125,9 & 41,7 & 165,5 & 32,5 & 31,1 \\
\hline D & 165,6 & 126,5 & 127,8 & 40,4 & 163,7 & 32,2 & 30,8 \\
\hline $\mathrm{E}$ & 165,3 & 131,1 & 127,3 & 39,1 & 166,0 & 31,1 & 30,1 \\
\hline $\mathrm{F}$ & 165,5 & 127,7 & 124,4 & 32,5 & 164,5 & 22,5 & 21,5 \\
\hline
\end{tabular}

${ }^{1}$ See Table 1 for WPC formulation.

${ }^{\mathrm{b}}$ Peak temperature of first melting.

${ }^{\mathrm{c}}$ Onset temperature of crystallization.

${ }^{\mathrm{d}}$ Peak temperature of crystallization.

${ }^{\mathrm{e}}$ Enthalpy of crystallization.

${ }^{\mathrm{f}}$ Peak temperature of second melting.

${ }^{g}$ Enthalpy of second melting.

${ }^{\text {h }}$ Degree of crystallization calculated with the enthalpy of second melting. 
Higher peak $T_{c}$ was due to faster crystallization of polymer chains upon cooling. In general, the polymer molecular chains can crystallize by themselves thorough a self- nucleation effect or by introducing a nucleating agent (Cheng 1985, Demir et al. 2005, Mohanty et al. 2006, Doan et al. 2007). The differences in the $T_{c}$ values of WPCs were mainly due to use of lignocellulosic filler, coupling agent or zeolites.

The degree of crystallinity decreased increasingly from 20 to $50 \mathrm{wt} \%$ zeolite content, the highest crystallinity value being recorded for WPCs at $50 \mathrm{wt} \% \mathrm{WF}, 10 \mathrm{wt} \%$ zeolite and $3 \mathrm{wt} \%$ MAPP (40,8 $\%)$. This may be due to the fact that WF (40 wt \%) and zeolite ( $\mathrm{wt} \% 10)$ introduced in the PP matrix can serve as a nucleating agent. The existence of filler can have an effect on the crystallinity behavior of the plastic composites. Accordingly, in this study, the effect of the zeolite content on the crystallization degree of the WPC samples was significant.

The second melting enthalpy of the control group (Group A) was found to be 33,2 J/g. Except the group B (50wt \% PP+ 50wt \% WF $+10 \mathrm{wt} \%$ zeolite $+3 \mathrm{wt} \%$ MAPP) the enthalpy of second melting of the samples decreased with increasing content of the zeolite flour. The second melting enthalpy of the WPCs decreased from 32,5 to $22,5 \mathrm{~J} / \mathrm{g}$ as the zeolite content increased from 20 to $50 \mathrm{wt} \%$. This result indicated that thermal stability of the wood/polypropylene composites increased with increasing the zeolite content. The zeolite absorbed more heat energy in the melting of the plastic composites.

\section{CONCLUSIONS}

The results of the present study revealed that water resistance of the WPCs improved with increasing zeolite content while the flexural and tensile properties of WPCs decreased. The lower flexural and tensile properties might be due to poor dispersion of zeolite in the polypropylene matrix. This is an evidence of poor adhesion and weak stress transfer efficiency.

The thermal stability of the wood/polypropylene composites increased with increasing the zeolite content. It should be noted that WPCs having a higher amount of the zeolite had higher residues at $500{ }^{\circ} \mathrm{C}$ due to the presence of silicates in the surface region of the zeolites. The DSC analysis showed that the melt crystallization enthalpies and degree of crystalization of WPCs decreased with increasing zeolite content. The decrease in the $\mathrm{T}_{\mathrm{c}}$ and $\mathrm{X}_{\mathrm{c}}$ indicated that zeolite was the poor nucleating agent for the WPCs. Based on the findings obtained from the present study, a 40/10/50/3 formulation of the WF/ zeolite/polypropylene/MAPP can be used in manufacturing WPC with satisfactory service results.

\section{REFERENCES}

Anonymus, 2011. Wood-plastic composites: Technologies and global markets. <http://www. bccresearch.com/pressroom/report/code/PLS034B > [cited 22.09.2016]. ISBN: 1596237651.

Ashori, A.; Nourbakhsh, A. 2009. Mechanical behaviour of agro-residue reinforced polyethylene Composites. Journal of Applied Polymer Science 111: 2616-2620.

ASTM International. 2001. Standard Specification for Polyolefin-Based Plastic Lumber Decking Boards. ASTM D 6662-13. West Conshohocken, PA, Pennsylvania.

ASTM International. 2008. Standard test method for transition temperatures and enthalpies of fusion and crystallization of polymers by differential scanning calorimetry. ASTM D3418-08b. West Conshohocken, PA, Pennsylvania. 
Aydemir, D.; Civi, B.; Alsan, M.; Wang, X.A. 2016. Mechanical, morphological and thermal properties of nano-boron nitride treated wood materials. Maderas Cienc Tecnol 18(1): 19-32.

Ayrilmis, N.; Kaymakci, A. 2013. Fast growing biomass as reinforcing filler in thermoplastic composites: Paulownia elongata wood. Industrial Crops and Products 43: 457-464.

Ayrilmis, N.; Kaymakci, A.; Akbulut, T.; Elmas, G.M. 2013. Mechanical performance of composites based on wastes of polyethylene aluminum and lignocellulosics wastes. Composites Part $B$ : Engineering 47: 150-154.

Bledzki, A.K.; Gassan, J. 1999. Composites reinforced with cellulose based fibres. Progress in Polymer Science 24: 221-274.

Bledzki, A.K.; Reihmane, S.; Gassan, J. 1998. Thermoplastics reinforced with wood fillers: a literature review. Polymer-Plastics Technology and Engineering 37: 451-468.

Carus, M.; Gahle, C. 2008. Market \& Future trends for Wood Polymer Composites in Europe: The example of Germany, Woodhead Publishing Ltd, Cambridge, England.

Chang, B.P; Akil, H.M; Nasir, R.M. 2013. Mechanical and Tribological Properties of Zeolitereinforced UHMWPE Composite for Implant Application, Procedia Engineering 68: 88 - 94.

Cheng, J.Q. 1985. Wood Science. Beijing, Chinese Forestry Publishers.

Demir, H.; Arkıs, E.; Balkose, D.; Ulku, S. 2005. Synergistic effect of natural zeolites on flame reterdant additives. Polymer Degradation and Stability 89: 478-483.

Demir, H.; Atikler, U.; Balköse, D.; Tihminlıglu, F. 2006. The effect of fiber surface treatments on the tensile and water sorption properties of polypropylene-luffa fiber composites. Composites Part A: Applied Science and Manufacturing 37: 447-456.

Doan, T.T.L. Brodowsky, H.; Mäder, E. 2007. Jute fibre/polypropylene composites. II. Thermal, hydrothermal and dynamic mechanical behavior. Composites Science and Technology 67: 2707-2714.

International Organization for Standardization. ISO. 2010. Determination of Flexural Properties, ISO 178:2010. Geneva.

International Organization for Standardization. ISO. 2012. Determination of Tensile Properties - Part 1: General Principles, ISO 527:2012. Geneva.

International Organization for Standardization. ISO. 2008. Determination of Water Absoption, ISO 62:2008. Geneva.

Khonsari, A.; Taghiyari, H.R.; Karimi, A.; Tajvidi, M. 2015. Study on the effects of wood flour geometry on physical and mechanical properties of wood-plastic composites. Maderas- Cienc Tecnol 17(3): 545-558.

Kidalova, L.; Stevulova, N.; Terpakova, E.; Sicakova, A. 2012. Effective Utilization of Alternative Materials in Lightweight Composites. Journal of Cleaner Production 34: 116-119.

Kim, H.S.; Kim, H.J. 2008. Influence of the zeolite type on the mechanical-thermal properties and volatile organic compound emissions of natural $\square$ flour $\square$ filled polypropylene hybrid composites. Journal of Applied Polymer Science 110: 3247-3255.

Kordkheili, H.Y.; Farsi, M.; Rezazadeh, Z. 2013. Physical, mechanical and morphological properties of polymer composites manufactured from carbon nanotubes and wood flour. Composites Part B: Engineering 44: 750-755. 
Mengeloglu, F.; Karakus, K. 2008. Thermal degradation, mechanical properties and morphology of wheat straw flour filled recycled thermoplastic composites. Sensors 8: 500-519.

Mohanty, S.; Verma, S.K.; Nayak, S.K. 2006. Dyamic mechanical and thermal properties of MAPE treated jute/HDPE Composites. Composites Science and Technology 66: 538-547.

Naik, S.N.; Vaibhav, V.G.; Prasant, K.R.; Ajay, K.D. 2007. Production of first and second generation biofuels: A comprehensive review. Renewable \& Sustainable Energy Reviews 14: 578-597.

Najafi, S.K.; Hamidina, E.; Tajvidi, M. 2005. Mechanical properties of composites from sawdust and recycled plastics. Journal of Applied Polymer Science 100: 3641-3645.

Nafchi, H.R.; Abdouss, M.; Najafi, S.K.; Gargari, R.M.; Mazhar, M. 2015. Effects of nanoclay particles and oxidized polypropylene polymers on improvement of the thermal properties of wood plastic composite. Maderas- Cienc Tecnol 17(1): 45-54.

Safdari, V.; Khodadadi, H.; Hosseinihashemi, S.K.; Ganjian, E. 2011. The effects of poplar bark and wood content on the mechanical properties of wood-polypropylene composites. Bioresources 6: 5180-5192.

Samariha, A.; Hemmasi, A.H.; Ghasemi, I.; Bayzar, B.; Nemati, M. 2015. Effect of nanoclays contents on properties, of bagasse flour/reprocessed high density polyethylene/nanoclays composites. Maderas- Cienc Tecnol 17(3): 637-646.

Uysal, B.; Yorur, H. 2013. The effect of steam treatment on bonding strength of impregnated wood materials. Journal of Adhesion Science and Technology 27: 896-904.

Valles-Rosales, D.J.; Méndez-González, L.C.; Rodríguez-Picon, L.A.; Valle-Carrasco, A.D.; Alodan, H. 2016a. Wood chile peppers stalks-plastic composite production. Maderas- Cienc Tecnol 18(1): 179-190.

Valles-Rosales, D.J.; Rodríguez-Picon, L.A.; Méndez-González, L.C.; Valle-Carrasco, A.D.; Alodan, H. 2016b. Analysis of the mechanical properties of wood-plastic composites based on agriculture chili pepper waste. Maderas- Cienc Tecnol 18(1): 43-54.

Väisänen, T. 2016. Effects of Thermally Extracted Wood Distillates on the Characteristics of Wood-Plastic Composites. Department of Applied Physics, University of Eastern Finland, Dissertations in Forestry and Natural Sciences, number 222, ISSN: 1798-5668, Finland.

Walker, J.C.F. 2006. Primary Wood Processing: Principles and Practise, Springer, Dordrecht, The Netherlands.

Wang, W.; Zhang, W.; Chen, H.; Zhang, S.; Li, J. 2015. Synergistic effect of synthetic zeolites on flame-retardant wood-flour/polypropylene Composites. Construction and Building Materials 79: $337-344$.

Yemele, M.C.N.; Koubaa, A.; Cloutier. A.; Soulounganga, P.; Walcott, M. 2010. Effect of bark fibre content and size on mechanical properties of bark/HDPE composites. Composites Part B: Engineering 41: 131-137.

Yorur, H. 2016. Utilization of waste polyethylene and its effects on physical and mechanical properties of oriented strand boards. Bioresources 11: 2483-2491. 